\title{
BARRIERS TO THE IMPLEMENTATION OF ISONIAZID PREVENTIVE THERAPY AMONG CHILDREN UNDER FIVE YEARS OLD IN CLOSE CONTACT WITH SPUTUM SMEAR-POSITIVE TB PATIENTS
}

\author{
Tirsa Hizkia Saverina Nugroho ${ }^{1 *}$, Anindita Soetadji ${ }^{2}$, Dea Amarilisa Adespin ${ }^{3}$, Stefani Candra \\ Firmanti $^{4}$ \\ ${ }^{1}$ Undergraduate Program, Faculty of Medicine, Diponegoro University, Semarang, Indonesia \\ ${ }^{2}$ Department of Pediatrics, Faculty of Medicine, Diponegoro University, Semarang, Indonesia \\ ${ }^{3}$ Department of Public Health, Faculty of Medicine, Diponegoro University, Semarang, Indonesia \\ ${ }^{4}$ Department of Microbiology, Faculty of Medicine, Diponegoro University, Semarang, Indonesia \\ *Corresponding author, E-mail: tirshizkia@gmail.com
}

\begin{abstract}
Background: The implementation of isoniazid preventive therapy (IPT) among children under five years old in close contact with sputum smear-positive TB patients is still low. Only 21,7\% of children implemented the IPT in Central Java in 2017. Assessment of the barriers to IPT implementation needs to be carried out in the control of child TB cases. Objective: To analyzed the barriers to IPT implementation among children under five years old in close contact with sputum smear-positive TB patients. Methods: A cross-sectional study was conducted among children (age <5 years) in close contact with sputum smear-positive TB patients. Data were collected from KRMT Wongsonegoro Hospital, Dr. Adhyatma, MPH Hospital, Puskesmas Kedungmundu, and Puskesmas Bandarharjo. Structured questionnaires were used to obtain sociodemographic information and to identify associated barriers to IPT implementation. The data were analyzed using Fisher's exact test. Results: The majority $(93,3 \%)$ of the total subject (75) of this study did not implement the IPT. The results of the bivariate analysis showed that distance to health facilities $(\mathrm{p}=0.024)$, perceived barriers $(\mathrm{p}=0.016)$, and cues to action $(\mathrm{p}=0.001)$ had a significant association as barriers to IPT implementation. Meanwhile age $(\mathrm{p}=0.622)$, gender $(\mathrm{p}=2.121)$, education level $(\mathrm{p}=0.073)$, economic level $(\mathrm{p}=0.521)$, knowledge level $(\mathrm{p}=0.166)$, and perceived threats $(\mathrm{p}=0.316)$ had no significant association as barriers to IPT implementation. Conclusion: IPT implementation rate was low. The barriers were distance to health facilities, perceived barriers, and cues to action.
\end{abstract}

Keywords: Barrier, child, isoniazid preventive therapy, sputum smear-positive TB patients

\section{INTRODUCTION}

Tuberculosis (TB) is the major cause of death in the world from an infectious agent. It is estimated that there are 10 million people who suffered from TB in the world in 2018, 1 million of whom are children [1]. The findings of TB in children in Indonesia amounted to $9 \%$ of the total TB cases in all age groups in 2015, while in Central Java TB cases in children had a share of $11.16 \%$ in $2018[2,3]$.

Children under five years old in close contact with adult sputum smear-positive TB patients are the individuals most susceptible to TB infection. The government launched the Isoniazid Preventive Therapy (IPT) program and regulated in the Regulation of the Minister of Health Republic of Indonesia Number 67 Year 2016 to prevent the growth of child TB cases [4]. IPT significantly reduced the incidence of active TB. The percentage of IPT successfulness in reducing the risk of active TB in children is $59 \%$ and $96.3 \%$ in people with HIV/AIDS [5].
The implementation of IPT in children is still low. The percentage of children who missed the IPT in the world in 2018 was $73 \%$ and $90 \%$ in Indonesia [1]. The Central Java Health Office reported that the percentage of children under five years old who have implemented IPT was only $21.7 \%$ with a target of $30 \%$ [6]. Risk factors such as demographic factors, structural factors, and health belief model (HBM) can cause a low rate of IPT implementation $[7,8]$.

Demographic factors like gender and age can influence the implementation of IPT. Research conducted in Kenya stated that girls had a 1.9 times greater risk of not carrying out IPT than boys [9]. A study conducted in Rwanda shown that children aged $>3$ had a 29 times greater risk of not getting the IPT [10]. HBM describes factors such as knowledge, attitude, beliefs, and perceptions that influence patient behavior, including treatment compliance. HBM components such as perceived threats and perceived benefits are the strongest predictor of 
Tirsa Hizkia Saverina Nugroho, Anindita Soetadji,

Dea Amarilisa Adespin, Stefani Candra Firmanti

TB treatment adherence [11]. Other research on medication adherence stated that the five components of HBM (perceived vulnerability, perceived seriousness, perceived benefits, perceived barriers, and self-efficacy) affected treatment compliance [12].

This study aimed to identify the barriers to IPT implementation in children under five years old in close contact with sputum smearpositive TB patients. This information is urgent as a basis for intervention in controlling child TB cases.

\section{METHODS}

An analytic observational study with a cross-sectional design was conducted to assess the prevalence and association of barriers to IPT implementation [13]. This research was approved by the Health Research Ethics Committees of the Faculty of Medicine, Diponegoro University. The ethical clearance number is 105/EC/KEPK/FK-UNDIP/VI/2020. This research was conducted at KRMT Wongsonegoro Hospital, Dr. Adhyatma, MPH Hospital, Puskesmas Kedungmundu, and Puskesmas Bandarharjo in June-August 2020.

The subjects of the study were 75 children aged 0-5 years, had close contact (contact $>8$ hours/day or lived in the same house) with adult sputum-smear positive TB patients, and were not suffering/had ever suffered from TB disease or undergoing TB treatment. The medical records of sputum smear-positive TB patients in KRMT Wongsonegoro Hospital, Dr. Adhyatma, MPH Hospital, Puskesmas Kedungmundu, and Puskesmas Bandarharjo was used to obtain the secondary data in order to select the subjects. Selection of subjects using a consecutive sampling method.

The independent variables in this study were age, gender, education level, economic level, distance to health facilities, level of knowledge, perceived threats, perceived barriers, and cues to action. The dependent variable in this study was the implementation of IPT in children under five years old in close contact with sputum smear-positive TB patients. The questionnaires that had been tested for validity was filled out by the parents/guardians of the research subjects via offline or online meeting to obtain the primary data. The data that had been collected were analyzed with univariate analysis, followed by Fisher's exact bivariate test. A p-value of $<0.05$ was considered statistically significant. The prevalence value is expressed by the value of the prevalence ratio (PR) with a confidence interval of $95 \%(95 \% \mathrm{CI})$.

\section{RESULTS}

The characteristics of the research subjects are shown in Table 1 . The results of this study were obtained from 75 children, 43 children were male and 32 children were female. The average child's age was $2.7 \pm 1.1 \mathrm{SD}$ with an age range of $0-5$ years old. The average parent/guardian's age was $35.4 \pm 8.8 \mathrm{SD}$ with an age range of 22-60 years old. Most parents/guardians had high education levels (77.3\%). The subject's average economic level was in the sufficient category $(753,388.8 \pm$ $317,034.55 \mathrm{SD})$ with a family income per month ranging from IDR 187,500 - IDR 2,200,000. Most research subjects had a long distance to health facilities $(70.7 \%)$. More than half of parents/guardians had a high knowledge level $(70.7 \%)$, positive perceived threats $(80 \%)$, and positive perceived barriers $(54.7 \%)$, contrary to positive cues to action $(25.3 \%)$.

The results of bivariate analysis of barriers to IPT implementation in children under five years old in close contact with sputum smear-positive TB patients are shown in Table 2. The results of the bivariate analysis showed that distance to health facilities $(\mathrm{p}=0.024)$, perceived barriers $(\mathrm{p}=0.016)$, and cues to action $(\mathrm{p}=0.001)$ had a significant association as barriers to IPT implementation. The prevalence of long distance to health facilities was 11.556 times greater to be a barrier to IPT implementation. 
Table 1. Characteristic of research subjects

\begin{tabular}{ll}
\hline Characteristics & $\mathbf{N}=\mathbf{7 5}(\boldsymbol{\%})$ \\
\hline Child's age, years, mean \pm SD & $2.7 \pm 1.1$ \\
Child's gender, male & $43(57.3)$ \\
Parent/guardian's age, year, mean \pm SD & $35.4 \pm 8.8$ \\
Parent/guardian's education level & \\
Did not finish elementary school & $1(1.3)$ \\
Elementary school graduate & $3(4)$ \\
Middle school graduate & $13(17.3)$ \\
High school graduate & $54(72)$ \\
D3/Bachelor degree & $4(5,3)$ \\
Economic level & \\
Insufficient & $10(13.3)$ \\
Sufficient & $65(86.7)$ \\
Distance to health facilities & $22(29.3)$ \\
<4 km & $53(70.7)$ \\
$\geq 4$ km & $53(70.7)$ \\
Knowledge level & $22(29.3)$ \\
High & \\
Low & $15(20)$ \\
Perceived threats & $60(80)$ \\
Negative & \\
Positive & \\
Perceived barriers & $34(45.3)$ \\
Negative & $41(57)$ \\
Positive & \\
Cues to action & \\
Negative & $56(74.7)$ \\
Positive & $19(25.3)$ \\
\hline
\end{tabular}

\section{DISCUSSION}

This study involved 75 research subjects, 70 of whom did not implement IPT. This shows that the rate of IPT implementation is still low and can have a negative effect on controlling TB cases in children. Identification of the barriers to IPT implementation was carried out to overcome this problem.

The demographic factor that had a significant association as a barrier to IPT implementation in this study was the distance to health facilities with a p-value of 0.024 (PR 11.556, 95\% CI 1.211-110.28). The longdistance to health facilities had a greater prevalence of 11.556 times to be a barrier to IPT implementation in children under five years old. This result is in line with studies in Kudus $(p=0.000)$ and Bogor $(p=0.000)$ regarding TB treatment compliance. The long-distance to health facilities makes it difficult for patients because the access is not available, transportation costs are expensive, and patients feel their time wasted because they have to go to distant health facilities. Research by Yulisetyaningrum et al. in 2019 stated that regulating the distribution of health facilities was important to control this issue [14-16].

Other demographic factors, namely child's age $(p=0.622)$, child's gender $(p=2.121)$, economic level $(\mathrm{p}=0.521)$, and parent/guardian's education level $(\mathrm{p}=0.073)$ did not have a significant association as a barrier to the implementation of IPT in this study. This can be influenced by the limited number of research subjects as indicated by the wide confidence interval in this study [17]. The majority of children who did not undergo IPT were $>2$ years old, although age did not affect this study, this result is in line with a study in India regarding IPT adherence (95\% CI 0.7-1.6) [18]. Parents worry about their younger children more because they are considered more susceptible to 
Tirsa Hizkia Saverina Nugroho, Anindita Soetadji,

Dea Amarilisa Adespin, Stefani Candra Firmanti

disease, and older children are usually embarrassed if they look different from their peers $[10,19]$. The gender factor that did not have a significant association as a barrier is in line with studies in India (95\% CI 0.8-1.5), New Zealand $(p=0.09)$, and Nigeria $(p=0.750)$ regarding adherence to child medication [1820]. These results, however, contrast with findings from a research that was conducted in Kenya where boys were influential as a factor in the failure of IPT $(p=0.02)$ [21].

The IPT program has been facilitated by the Government according to Regulation of the Minister of Health Republic of Indonesia Number 67 Year 2016 concerning Tuberculosis Control. That makes patients free from the burden to pay for IPT drugs so that it can result in an economic level not affect a barrier to IPT implementation [4]. This result is in line with studies in Jayapura $(\mathrm{p}=0.42)$ and Tanzania $(p=0.489)[22,23]$. Another demographic factor, namely the education level did not have a significant association as a barrier in this study. This result contrasts with findings from studies on TB treatment compliance which was conducted in Indonesian Lung Hospitals $(p=0.000)$ and Ethiopia $(p<0.001)$, but is in line with studies in Bogor $(\mathrm{p}=0.906)$ and Banyumas $(\mathrm{p}=0.569) \quad[15,24-26]$. Patients with higher education tend to understand more about the dangers of incomplete therapy, giving rise to perceived threats and thus can be the cues to comply with treatment, but not all highly educated patients have good knowledge of TB [26].

The structural factor in the form of knowledge level did not have a significant association as a barrier to the implementation of IPT in this study $(p=0.166)$. This result is in line with studies in Palembang $(\mathrm{p}=0.059)$ and Bogor $(\mathrm{p}=0.079)$ regarding $\mathrm{TB}$ treatment adherence $[14,15]$. Knowledge can predict an individual perceived threats, which in turn can be a motivation to do healthy behaviors [27]. The insignificant results in this study could be related to Notoatmodjo's statement which says that the cognitive domain has six levels, namely knowledge, comprehension, application, analysis, synthesis, and evaluation. A person who is at the level of "knowing" might not understand how to implement the information that they have [28]. In this study, perceived threats did not have a significant association as a barrier to IPT implementation $(p=0.316)$. That also can be related to an individual knowledge level. The insignificant result in this study is in line with a study in Ethiopia $(p=0.061)$. A similar result was obtained from research in Pekalongan which stated that perceived vulnerability, which is a component of perceived threats, did not affect treatment adherence $(\mathrm{p}=0.272)[27,29]$.

Factors according to HBM theory that had a significant association as a barrier to IPT implementation in this study were perceived barriers $(p=0.016)$ and cues to action $(p=0.001)$. Perceived barriers are an individual perception of the barriers that will be faced in carrying out health behaviors [30]. The significant result of this study is in line with studies in Iran $(p=0.05)$ and Ethiopia $(p=0.032)$ [11,27]. Similar results were also found in studies in Pekalongan $(\mathrm{p}=0.000)$ and Banjarmasin $(\mathrm{p}=0.009)$ regarding treatment adherence $[31,32]$. Research on IPT adherence that was conducted in Indonesia found that the barriers complained about by respondents were transportation costs and the difficulty of administering drugs to children [33].

Cues to action motivate a person to do healthy behaviors. This motivation can be external (information from family, friends, health workers, or the media) and internal (symptoms of the disease) [34]. The significant result in this study is in line with studies in Ethiopia regarding TB treatment adherence $(\mathrm{p} \leq 0.001)$ [27]. Research in Surakarta $(\mathrm{p}<0.001)$ and Pekalongan $(\mathrm{p}=0.000)$ also showed that cues to action affected treatment compliance [32,35]. Research on IPT adherence in Indonesia found that respondents who did not give IPT to their children thought that their children were healthy so they did not need treatment. Other respondents said that health workers did not provide information about IPT so that cues to action could not be generated [33].

This study has several limitations, aside from the limited number of research subjects, the use of self-reported questions on knowledge of patients on tuberculosis, contact screening, and INH prophylaxis, could lead to recall and social desirability biases [36]. 
Table 2. Bivariate analysis of barriers to IPT implementation in children under 5 years old in close contact with sputum smear-positive TB patients

\begin{tabular}{|c|c|c|c|c|c|}
\hline Characteristics & $\begin{array}{c}\text { Did not } \\
\text { implement IPT }\end{array}$ & $\begin{array}{c}\text { Implemented } \\
\text { IPT }\end{array}$ & PR & $95 \% \mathrm{CI}$ & p-value \\
\hline \multicolumn{6}{|l|}{ Age $(n, \%)$} \\
\hline$\leq 2$ years & $26(37.1)$ & $2(40)$ & 0.886 & $0.139-5.658$ & 0.622 \\
\hline$>2$ years & $44(62.9)$ & $3(60)$ & & & \\
\hline \multicolumn{6}{|l|}{ Gender (n\%) } \\
\hline Male & $41(58.6)$ & $2(40)$ & 0.361 & $0.333-13.505$ & 2.121 \\
\hline Female & $29(41.4)$ & $3(60)$ & & & \\
\hline \multicolumn{6}{|l|}{ Education level (n,\%) } \\
\hline Low & $14(20)$ & $3(60)$ & 0.167 & $0.025-1.095$ & 0.073 \\
\hline High & $56(80)$ & $2(40)$ & & & \\
\hline \multicolumn{6}{|l|}{$\begin{array}{l}\text { Distance to health } \\
\text { facilities }(n, \%)\end{array}$} \\
\hline Far & $52(74.3)$ & $1(20)$ & 11.556 & $1.211-110.285$ & $0.024 *$ \\
\hline Near & $18(25.7)$ & $4(80)$ & & & \\
\hline \multicolumn{6}{|l|}{ Economic level $(\mathbf{n}, \%)$} \\
\hline Insufficient & $9(12.9)$ & $1(20)$ & 0.590 & $0.059-5.888$ & 0.521 \\
\hline Sufficient & $61(87.1)$ & $4(80)$ & & & \\
\hline \multicolumn{6}{|l|}{ Knowledge level (n,\%) } \\
\hline Low & $22(31.4)$ & $0(0)$ & - & - & 0.166 \\
\hline High & $48(68.6)$ & $5(100)$ & & & \\
\hline \multicolumn{6}{|l|}{ Perceived threats $(\mathrm{n}, \%)$} \\
\hline Negative & $15(21.4)$ & $0(0)$ & - & - & 0.316 \\
\hline Positive & 55 (78.6) & $5(100)$ & & & \\
\hline \multicolumn{6}{|l|}{ Perceived barriers (n,\%) } \\
\hline Negative & $29(41.4)$ & $5(100)$ & - & - & $0.016 *$ \\
\hline Positive & $41(58.6)$ & $0(0)$ & & & \\
\hline \multicolumn{6}{|l|}{ Cues to action $(\mathrm{n}, \%)$} \\
\hline Negative & $56(80)$ & $0(0)$ & - & - & $0.001^{*}$ \\
\hline Positive & $14(20)$ & $5(100)$ & & & \\
\hline
\end{tabular}

\section{CONCLUSION}

IPT implementation rate in this study was still low. Bivariate analysis results showed that the distance to health facilities, perceived barriers, and cues to action had a significant association as barriers to IPT implementation in children under five years old, of which had close contact with sputum smear-positive TB patients.

Healthcare workers are advised to educate adult TB patients who had close contact with children under five years old about IPT. A proper health facility distribution needs to be taken into account to ensure easy access for patients. Further research needs to be conducted using a larger sample size and measurements that yield objective data.

\section{Conflict of interest}

The authors declare that there is no conflict of interest.

\section{Funding} this article.

There was no specific funding provided for

\section{Author Contributions}

Conceptualization, THSN; methodology, THSN; formal analysis, THSN; investigation, THSN; resources, THSN; data curation, THSN; writing - original draft preparation, THSN; writing - review and editing, SCF, DAA, and AS; 
supervision, SCF, DAA, and AS; project administration, THSN.

Acknowledgments

Authors would like to thank the heads and staffs of KRMT Wongsonegoro Hospital, Adhyatma, MPH Hospital, Puskesmas Kedungmundu, Puskesmas Bandarharjo, and other parties who has helped in every process of this research.

\section{REFERENCES}

[1] World Health Organization. Tuberculosis Global Report 2019. World Health Organization. 2019.

[2] Dinas Kesehatan Provinsi Jateng. Profil Kesehatan Provinsi Jawa Tengah Tahun 2018. Semarang: Dinas Kesehatan Provinsi Jateng; 2018.

[3] Direktorat Jenderal Pencegahan dan Pengendalian Penyakit. Petunjuk Teknis Manajemen dan Tatalaksana TB Anak. Jakarta: Kementerian Kesehatan Republik Indonesia; 2016.

[4] Menteri Kesehatan Republik Indonesia. Peraturan Menteri Kesehatan Republik Indonesia Nomor 67 Tahun 2016 tentang Penanggulangan Tuberkulosis. 2016;

[5] Briggs MA, Emerson C, Modi S, Taylor NK, Date A. Use of isoniazid preventive therapy for tuberculosis prophylaxis among people living with HIV/AIDS: a review of the literature. Journal of Acquired Immune Deficiency Syndromes [Internet]. 2015 Apr 15;68 Suppl 3(Suppl 3):S297-305. Available from:

https://pubmed.ncbi.nlm.nih.gov/25768869

[6] Peraturan Gubernur Jawa Tengah. Rencana Aksi Daerah Penanggulangan Tuberkulosis Provinsi Jawa Tengah Tahun 2018-2023. Peratur Gubernur Jawa Tengah [Internet]. 2018; Available from: http://jdih.jatengprov.go.id/downloads/produk _hukum/pergub/pergub_tahun_2018/pergub_9 3_th_2018.pdf

[7] Grace SG. Barriers to the implementation of isoniazid preventive therapy for tuberculosis in children in endemic settings: A review. Journal of Paediatrics and Child Health. 2019;55(3):278-84.
[8] Paul NI, Gabriel-Job N. Adherence to isoniazid preventive therapy (IPT) among children in close contact with adult pulmonary tuberculosis (PTB) patients. Journal of Advances in Medicine and Medical Research. 2019;30(11):1-8.

[9] Burmen B, Mutai K, Malika T. Isoniazid preventative therapy uptake for child household contacts of tuberculosis index cases, Kisumu County, Kenya, 2014-2015. Journal of Public Health in Africa [Internet]. 2019 Jun 12;10(1):827. Available from: https://pubmed.ncbi.nlm.nih.gov/31285812

[10] Birungi FM, Graham S, Uwimana J, van Wyk B. Assessment of the isoniazid preventive therapy uptake and associated characteristics: A cross-sectional study. Tuberculosis Research and Treatment. 2018;2018:1-9.

[11] Azizi N, Karimy M, Salahshour VN. Determinants of adherence to tuberculosis treatment in Iranian patients: Application of health belief model. Journal of Infection in Developing Countries. 2018;12(9):706-11.

[12] Kamran A, Sadeghieh Ahari S, Biria M, Malepour A, Heydari H. Determinants of patient's adherence to hypertension medications: Application of health belief model among rural patients. Annals of Medical and Health Science Research [Internet]. 2014 Nov;4(6):922-7. Available from:

https://pubmed.ncbi.nlm.nih.gov/25506487

[13] Kesmodel US. Cross-sectional studies - what are they good for? Acta Obstetricia et Gynecologica Scandinavica. 2018;97(4):38893.

[14] Hendesa A, Tjekyan RMS, Pariyana. Hubungan pengetahuan, sikap, dan dukungan keluarga dengan kepatuhan berobat pada pasien tuberkulosis paru di RS Paru Kota Palembang. Majalah Kedokteran Sriwijaya. 2018;4.

[15] Wulandari D. Analisis faktor-faktor yang berhubungan dengan kepatuhan pasien tuberkulosis paru tahap lanjutan untuk minum obat di RS rumah sehat terpadu tahun 2015. Jurnal Administrasi Rumah Sakit. 2015;2(1):17-28.

[16] Yulisetyaningrum Y, Hidayah N, Yuliarti R. Hubungan jarak rumah dengan kepatuhan 
minum obat pada pasien TBC di RSI Sunan Kudus. Jurnal Ilmu Keperawatan dan Kebidanan. 2019;10(1):248.

[17] du Prel J-B, Hommel G, Röhrig B, Blettner M. Confidence interval or p-value?: part 4 of a series on evaluation of scientific publications. Deutsches Ärzteblatt International [Internet]. 2009/05/08. 2009 May;106(19):335-9. Available from: https://pubmed.ncbi.nlm.nih.gov/19547734

[18] Singh AR, Kharate A, Bhat P, Kokane AM, Bali $S$, Sahu $S$, et al. Isoniazid preventive therapy among children living with tuberculosis patients: Is it working? A mixedmethod study from Bhopal, India. Journal of Tropical Pediatrics. 2017;63(4):274-85.

[19] Akahara C, Nwolisa E, Odinaka K, Okolo S. Assessment of antiretroviral treatment adherence among children attending care at a tertiary hospital in Southeastern Nigeria. Tanner M, editor. Journal of Tropical Medicine [Internet]. 2017;2017:3605850. Available from: https://doi.org/10.1155/2017/3605850

[20] Chan AHY, Stewart AW, Foster JM, Mitchell EA, Camargo CA, Harrison J. Factors associated with medication adherence in school-aged children with asthma. ERJ Open Research [Internet]. 2016 Jan 1;2(1):87-2015. Available from: http://openres.ersjournals.com/content/2/1/000 87-2015.abstract

[21] Okwara FN, Oyore JP, Were FN, Gwer S. Correlates of isoniazid preventive therapy failure in child household contacts with infectious tuberculosis in high burden settings in Nairobi, Kenya - a cohort study. BMC Infectious Disease. 2017;17(1):1-11.

[22] Ruru Y, Matasik M, Oktavian A, Senyorita R, Mirino Y, Tarigan LH, et al. Factors associated with non-adherence during tuberculosis treatment among patients treated with DOTS strategy in Jayapura, Papua Province, Indonesia. Global Health Action [Internet]. 2018 Jan 1;11(1):1510592. Available from: https://doi.org/10.1080/16549716.2018.15105 92

[23] Shayo GA, Moshiro C, Aboud S, Bakari M, Mugusi FM. Acceptability and adherence to isoniazid preventive therapy in HIV-infected patients clinically screened for latent tuberculosis in Dar es Salaam, Tanzania. BMC Infectious Disease [Internet]. 2015;15(1):368. Available from: https://doi.org/10.1186/s12879-015-1085-7

[24] Hakim A, Putri PM. Pengaruh latar belakang pendidikan pasien terhadap keteraturan pengobatan TB paru di puskesmas Wangon I Banyumas. Psycho Idea [Internet]. 2015;13(2). Available from: http://jurnalnasional.ump.ac.id/index.php/PSY CHOIDEA/article/view/1564

[25] Mindachew M, Deribew A, Tessema F, Biadgilign S. Predictors of adherence to isoniazid preventive therapy among HIV positive adults in Addis Ababa, Ethiopia. BMC Public Health [Internet]. 2011 Dec 12;11:916. Available from: https://pubmed.ncbi.nlm.nih.gov/22151609

[26] Setyaningrum R. Correlation between gender, age, education level, and working status with anti-tuberculosis drug uses (OATS) in patients with lung tb in Indonesia 2013. International Journal of Materials and Chemistry. 2018;1:7-13.

[27] Tola HH, Karimi M, Yekaninejad MS. Effects of sociodemographic characteristics and patients' health beliefs on tuberculosis treatment adherence in Ethiopia: a structural equation modelling approach. Infectious Diseases of Poverty [Internet]. 2017 Dec 15;6(1):167. Available from: https://pubmed.ncbi.nlm.nih.gov/29241454

[28] Notoatmodjo S. Promosi Kesehatan dan Perilaku Kesehatan. Jakarta; 2014.

[29] Widjanarko B, Saraswati LD, Ginandjar P. Perceived threat and benefit toward community compliance of filariasis' mass drug administration in Pekalongan district, Indonesia. Risk Management and Healthcare Policy. 2018;11:189-97.

[30] Glanz K, Rimer BK, Viswanath K. Health Behavior and Health Education. 4th ed. San Fransisco: Jossey-Bass; 2008. 47-50 p.

[31] Chairunisa C, Syamsul A, Rosida Lena. Faktor-faktor yang berhubungan dengan perilaku kepatuhan minum obat anti diabetes pada penderita diabetes melitus tipe 2 di 
Puskesmas Cempaka Banjarmasin. Homeostasis. 2019;2(1):43-54.

[32] Nurlaila N, Ginandjar P, Martini M. Faktorfaktor yang berhubungan dengan kepatuhan pengobatan masal di kelurahan non endemis filariasis Kota Pekalongan. Jurnal Kesehatan Masyarakat. 2017;5(4):455-66.

[33] Rutherford M, Hill P, Ruslami R, Maharani W, Alisjahbana B, Yulita I, et al. Adherence to isoniazid preventive therapy in Indonesian children: A quantitative and qualitative investigation. BMC Research Notes. 2012;5(7):1-7.

[34] Setiyaningsih R, Tamtomo D, Suryani N. Health belief model: Determinants of hypertension prevention behavior in adults at community health center, Sukoharjo, Central Java. Journal of Health Promotion and Behavior. 2016;01(03):160-70.

[35] Agustin DA, Prasetyo AA, Murti B. A path analysis on adherence to antiretroviral therapy among HIV/ AIDS patients at Dr. Moewardi Hospital, Surakarta using health belief model. Journal of Health Promotion and Behavior. 2018;03(01):48-55.

[36] Jahedi S, Mendez F. On the advantages and disadvantages of subjective measures. Journal of Economic Behavior and Organization. 2014 Feb 1;98. 